\title{
SPASIALISASI DALAM EKONOMI POLITIK KOMUNIKASI (Studi Kasus MRA Media)
}

\author{
Isma Adila \\ Mahasiswa Pascasarjana IImu Komunikasi UGM - 09/290522/PSP/03603
}

\begin{abstract}
Abstraksi
Ekonomi politik merupakan salah satu cara atau perspektif untuk melihat dan menganalisis suatu isu atau fenomena komunikasi. Konsep yang beriringan dengan Komodifikasi adalah komersialisasi. Komersialisasi adalah sebuah proses dimana struktur dan isi sebuah media diatur dan disesuaikan dengan keinginan konsumen atau khalayak, sehingga konten dari media tersebut hanya berdasarkan profit oriented saja, yang mengakibatkan isi media menjadi seragam, stereotipikal, dangkal dan tidak otentik. Terdapat beberapa pandangan ketika kita menelaah media dengan perspektif ekonomi politik. Diantaranya perspektif liberal dan perspektif kritis.
\end{abstract}

Kata Kunci: Ekonomi, Politik, Media, Spasialisasi

\section{Ekonomi Politik Komunikasi}

Ekonomi politik komunikasi adalah istilah yang digunakan secara umum untuk memadukan kerangka teoritik komunikasi dengan kerangkas teoritik politik dan ekonomi. Keterikatan pada kajian ekonomi dan politik menjadikan komunikasi menjadi ranah yang rentan terhadap pengaruh keduanya. Sebagai entitas yang dikonstruksi oleh media, apa yang disebut sebagai komunikasi sering merepresentasikan kepentingan ekonomi sekaligus politik tertentu. Vincent Mosco dalam bukunya "The Political Economy of Communication" menyebutkan bahwa definisi ekonomi politik adalah: "the study of relations, particularly the power relations, that mutually constitute the production, distribution, and consumption of resources". ${ }^{1}$

Atau dalam kata lain, pendekatan ini berdasar pada pengertian ekonomi politik sebagai studi mengenai relasi sosial, khususnya yang

\footnotetext{
1 Vincent Mosco, The Political Economy of Communication: Rethinking and Renewal, (London: Sage Publication, 1996), p. 25
} 
menyangkut relasi kekuasaan, baik dalam produksi, distribusi dan konsumsi sumber daya dalam ekonomi politik komunikasi. Sumber daya (dalam konteks media) dapat berupa koran, majalah, buku, kaset, film, dsb. Dalam menjelaskan relasi ini, perlu dipahami konsep tentang sejauh mana media mengambil posisi dalam kepentingan dan ideologi, dalam seting kepemilikan (ekonomi) dan setting kekuasaan (politik). Vincent Mosco menawarkan tiga konsep penting untuk mendekatinya, yaitu: komodifikasi, komersialisasi, spasialisasi dan strukturasi. $^{2}$

Ekonomi politik merupakan salah satu cara atau perspektif untuk melihat dan menganalisis suatu isu atau fenomena komunikasi. Dalam menganalisis isu atau fenomena tersebut, terdapat 4 karakter penting dari perspektif ekonomi politik yaitu, ekonomi politik berdasar dari kajian perubahan sosial dan trasformasi historis, menjelaskan tentang totalitas dari relasi sosial yang membentuk ranah ekonomi-sosial-budaya, berkomitmen pada filsafat moral dan memiliki ketertarikan atas nilai sosial serta prinsip moral, dan yang terakhir adalah sosial praksis yang artinya fenomena tersebut memang terjadi dalam realitas. Komodifikasi menurut Karl Marx ialah kekayaan masyarakat dengan menggunakan produksi kapitalis yang berlaku dan terlihat seperti, "kumpulan komoditas (barang dagangan) yang banyak sekali" ; komoditi milik perseorangan terlihat seperti bentuk dasar. ${ }^{3}$

Komodifikasi berhubungan dengan bagaimana proses transformasi barang dan jasa beserta nilai gunanya menjadi suatu komoditas yang mempunyai nilai tukar di pasar. Dalam artian siapa saja yang memulai kapital dengan mendeskripsikan sebuah komoditi maka ia akan memperoleh keuntungan yang sangat besar. Dalam lingkup institusi atau lembaga media, para pekerja media dilibatkan untuk memproduksi dan mendistribusikannya ke konsumen yang beragam. Konsumen dalam hal ini bisa khalayak pembaca media cetak, penonton televisi, pendengar radio. Nilai tambah dari komodifikasi akan sangat ditentukan sejauh mana produk media tersebut dapat memenuhi kebutuhan individual maupun sosial.

Konsep yang beriringan dengan Komodifikasi adalah komersialisasi. Komersialisasi adalah sebuah proses dimana struktur dan isi sebuah media diatur dan disesuaikan dengan keinginan konsumen atau khalayak, sehingga konten dari media tersebut hanya berdasarkan profit oriented saja, yang mengakibatkan isi media menjadi seragam, stereotipikal, dangkal dan tidak otentik. Spasialisasi, berkaitan dengan sejauh mana media mampu menyajikan produknya di depan audiens dalam batasan ruang dan waktu. Pada taraf ini maka struktur kelembagaan media, menentukan perannya di dalam

\footnotetext{
${ }^{2}$ Ibid, p. 139

${ }^{3}$ Ibid, p. 140
} 
memenuhi jaringan dan kecepatan penyampaian produk media di hadapan khalayak. Lebih jauh mengenai spasialisasi akan dijelaskan selanjutnya, pada poin tersendir selanjutnya.

Strukturasi dijelaskan sebagai proses dimana struktur sosial saling ditegakkan oleh para agen sosial, dan bahkan masing-masing bagian dari struktur mampu bertindak melayani bagian yang lain. Strukturasi menjelaskan tentang relasi ide antar agen masyarakat, proses sosial dan praktik sosial. Hasil akhir dari strukturasi adalah serangkaian hubungan sosial dan proses kekuasaan diorganisasikan di antara kelas, gender, ras dan gerakan sosial yang masing-masing berhubungan satu sama lain. Gagasan tentang strukturasi ini pada awalnya dikembangkan oleh Anthony Giddens. Strukturasi merupakan salah satu karakteristik yang penting dari teori struktural, yang didalammya menggambarkan tentang perubahan sosial sebagai proses yang mendeskripsikan bagaimana sebuah struktur diproduksi dan direproduksi oleh manusia yang berperan sebagai pelaku dalam struktur itu sendiri.

Terdapat beberapa pandangan ketika kita menelaah media dengan perspektif ekonomi politik. Jika Mosco menawarkan tiga perspektif, maka Peter Golding dan Graham Murdock dalam James Currant \& Michael Gurevitch, ${ }^{4}$ membagi perspektif ekonomi politik media ke dalam dua perspektif besar, yaitu perspektif liberal dan perspektif kritis. Perspektif liberal cenderung memfokuskan pada isu pertukaran pasar dimana konsumen akan secara bebas memilih komoditas media media sesuai dengan tingkat kemanfaatan dan kepuasan yang dapat mereka capai berdasarkan penawaran yang ada.

Semakin besar pasar memainkan peran, maka semakian luas pula pilihan yang dapat diakses oleh konsumen. Perspektif kritis, berasumsi bahwa media semestinya dilihat secara lebih holistik, karena produksi, distribusi dan konsumsi media berada dalam sebuah lingkungan sosial, ekonomi dan politik yang strukturnya saling mempengaruhi. Pada saat media kemudian mengambil peran dalam mendominasi isi pesan dan melegitimasi kelas dominan, pemilik modal bisa mengambil keuntungan atas preferensinya terhadap komodifikasi produk media. Pada tataran inilah perbincangan mengenai ideologi, kepentingan kekuasaan mendapat bahasan yang mendalam.

Dalam sudut pandang Marxis, preferensi pemilik modal memungkinkan institusi media mengambil peran sebagai penyebar kesadaran palsu yang melenakan khalayak (produksi teks merupakan bentuk laten dari kekuasaan yang bekerja dalam institusi media). Atau media dapat digunakan untuk melancarkan hegemoni dengan menutupi atau merepresentasikan kepentingan kelas berkuasa.

\footnotetext{
${ }^{4}$ James Currant and Michael Gurevitch, Mass Media and Society, (London: Edward Arnold, 1991), p.15
} 


\section{Spasialisasi}

Vincet Mosco dalam bukunya (Political Economy of Communication) menjelaskan bahwa Spasialisasi adalah "The process of overcoming the constraints of space and time in social life". Seorang sosiolog Prancis, Henri Levebfre berpendapat bahwa spasialisasi adalah "The institutional extension of corporate power in the communication industry", Henri Lefebvre (1979). Dalam bukunya (The Production of Space), Levebfre berpandangan bahwa ada beberapa level dari ruang, dari yang paling abstrak, kasat mata, ruang alamiah (ruang absolut) menuju ruangan yang lebih kompleks yang maknanya diproduksi secara sosial (sosial space). Argumen Lefebvre dalam The Production of Space adalah Ruang sebagai produk sosial, atau konstruksi sosial yang kompleks (berdasarkan nilai dan produksi sosial atas makna) yang mempengaruhi praktek ruang dan persepsi atas ruang.

Ruang sosial adalah produk sosial-ruang diproduksi sebagai cara tertentu yang menjadi alat berpikir dan bertindak. Itu tidak hanya berarti sebagai produksi namun juga berarti kontrol dan kemudian dominasi atau kekuasaan. Lefebvre berpendapat bahwa produksi sosial atas ruang kota adalah dasar bagi reproduksi masyarakat, disebabkan oleh kapitalisme. Oleh karena itu, konsep hegemoni yang diungkap oleh Antonio Gramsci digunakan sebagai acuan untuk menunjukkan bagaimana produksi sosial dari ruang diprakarsai oleh kelas hegemonik sebagai alat untuk mereproduksi dominasinya. Dalam bukunya, Mosco menjelaskan 4 Isu penting dalam spasialisasi, yaitu Communication and Concentration: Space as Institutional Extension, State, Globalization, dan Nationalism, Localism, and Socialism. Spasialisasi berhubungan dengan proses transformasi batasan ruang dan waktu dalam kehidupan sosial, dapat dikatakan juga bahwa spasialisasi merupakan proses perpanjangan institusional media melalui bentuk korporasi dan besarnya badan usaha media (Mosco, 1996). Ukuran badan usaha media dapat bersifat horizontal maupun vertikal.

\section{MRA Group (Media And Lifestyle Group Company)}

PT. Mugi Rekso Abadi (MRA), adalah korporasi yang dibentuk oleh pengusaha Adiguna Soetowo di tahun 1997, pada awalnya berbasis pada media cetak dan radio yang kemudian berekspansi ke bidang Lifestyle \& Hiburan / Makanan \& Minuman / Otomotif / Hotel \& Properties. MRA merupakan grup perusahaan yang menyajikan banyak alternatif untuk gaya hidup, target pasar yang dibidik adalah konsumen muda berusia 25-30 tahunan yang mempunyai motto work hard play hard, cerdas dan menuntut: penampilan prima serta, selera fashion yang up to date. Disini MRA memfasilitasi keinginan para konsumennya akan barang-barang branded, high 
lifestyle, serta kebutuhan akan media global. PT MRA Group memiliki anak perusahaan, antara lain:

a. Broadcast Media Group :

Radio Hard Rock FM Jakarta, Bandung Surabaya dan Bali

Traxx FM Jakarta dan Semarang

¿Radio Jakarta, Jogjakarta dan Bandung

Cosmopolitan FM, Jakarta

MNI (Media Network Indonesia)

b. Print Media Group :

Harper's Bazaar

Cosmopolitan

Cosmo Girl

FHM (For Him Magazine)

Autocar

Spice

Bali and Beyond

MotoRiders

MTV Trax

Good Housekeeping

Mother \& Baby

Trax Free

c. Automotive Group :

Harley Davidson

Ferrari

Maserati

Ducati

d. Food \& Beverage (F\&B) Group :

HardRock Cafe

HaagenDazs

e. Hotel dan Property :

Hard Rock Hotel Bali

Bvlgari Hotel Bali

f. Retail, Lifestyle and Entertainment :

Bvlgari

Bang and Olufsen

Home Vision Entertainment

Korporasi Bisnis MRA, sebenarnya tidak berada pada satu bidang industri yang sama (media), bidang broadcast media dan print media menjadi batu loncatan bagi MRA untuk memperluas bidang usahanya, baik secara konsentrasi vertikal maupun horizontal. Horizontal artinya bahwa bentuk badan usaha 
media tersebut adalah bentuk-bentuk konglomerasi, monopoli. Proses spasialisasi yang bersifat vertikal adalah proses integrasi antara induk perusahaan dan anak perusahaannya yang dilakukan dalam satu garis bisnis untuk memperoleh sinergi, terutama untuk memperoleh kontrol dalam produksi media (Mosco, 1996:175-176). Salah satu contohnya adalah radio berjaringannya yang terdiri dari empat radio sindikasi dengan segmen audiens yang berbeda, dan satu Media Network yang mendukung keberadaan jaringan radio sindikasi ini secara teknis. Pada lini bisnis lainnya saling mendukung dan memberi pengaruh dalam pembentukan dan pengarusutamaan lifestyle di Indonesia.

\section{Spasialisasi Dalam MRA Media}

Salah satu dari poin penting dari spasialisasi dalam industri media adalah globalisasi. Globalisasi dalam konteks ini dapat diartikan bahwa media massa membuka kondisi dunia yang borderless. Kondisi dunia tanpa batas ini mengakibatkan apa yang sering disebut dengan penyeragaman secara global dalam sistem, pola dan budaya komunikasi dunia dan Indonesia pada khususnya. Komunikasi global telah membawa dampak dalam hubungan internasional di berbagai bidang, termasuk militer, diplomatik, ekonomi, pendidikan, dan kebudayaan. Perkembangan global dalam bidang komunikasi dan kebudayaan tidak bisa hanya dilihat sebagai bagian dari sebuah neokolonialisme atau neoimperialisme media atau budaya.

Sekarang yang juga terjadi adalah fenomena teknologi komunikasi modern dan industri-industri media komersial gencar berekspansi ke seluruh dunia, ekspansi semacam ini terus berdampak luar biasa pada bagaimana budaya dibentuk, termasuk di Indonesia. Gejala kultural akibat proses globalisasi yang tidak dapat dihindari adalah munculnya homogenitas dari budaya pop. Dalam hal ini Indonesia masih dalam posisi sebagai negara penerima. Gejala ini bukan saja akan menyeragamkan selera dan simbol, tetapi juga melarutkan segala batas identitas dalam keseragaman. Perkembangan global dalam bidang komunikasi dan budaya ini juga membawa serta perhatian pada ideologi, kesadaran, dan hegemoni. Manipulasi yang dilakukan terhadap informasi dan citra publik mengkonstruksikan suatu ideologi dominan yang kuat yang membantu mendukung kepentingan material dan kultural para penciptanya.Kekuasaan atau dominasi mereka berasal dari kemampuan politik dan ekonomi dalam menyampaikan kepada masyarakat ideologi atau sistem ide yang mereka sukai. 


\section{Majalah Kosmopolitan}

Majalah, dalam hal ini Kosmopolitan merupakan salah satu media output yang disebut sebagai budaya pop, yang sekaligus menyerap budaya pop untuk kepentingan isi dan bentuknya. Kosmopolitan adalah salah satu merek majalah dari Amerika, dengan nama asli Cosmopolitan, pada awalnya dipasarkan di negara-negara Barat (Indonesia adalah negara ke-36 yang menerbitkannya) yang menonjolkan karakteristik Barat dengan menggunakan model-model dari negara Barat. Hal ini tampak dari penampilan majalahnya yang mengesankan majalah luar negeri, meskipun sebenarnya merupakan majalah versi Indonesia. Sosok selebriti dunia, seperti Blake Lively, Hillary Duff, Halle Barry, Vanessa Mae, Jennifer Lopez dan sebagainya, dalam balutan busana perancang dunia lengkap dengan aksesorisnya, menampilkan sosok perempuan sukses dari kalangan terpandang, kelas atas, dan dengan kehidupan yang mewah.

Kosmopolitan yang ditujukan untuk wanita muda berusia 20-30 tahun, sesuai dengan sampul majalah tersebut yang menampilkan selebriti-selebriti muda dengan usia yang kurang lebih sama dengan segmen yang ditujunya. Foto Cover majalah Kosmopolitan lebih mengedepankan unsur warna yang berusaha memukau dan memikat komunikan dengan keindahannya, unsur "memikirkan" dengan pendekatan intelektual-faktual justru dijauhkan karena foto sampul majalah ini tidak memerlukan verifikasi tentang kebenarannya. Sebagai majalah waralaba yang berasal dari Amerika, Kosmopolitan sarat dengan budaya pop. Hal itu tampak dalam gambar sampul dan foto-foto yang ada di dalam majalah Kosmopolitan, yang kemudian tampil sebagai ikon budaya pop, mulai dari peraganya yang berprofesi (sebagai artis, model, penyanyi, pemusik) dalam industri kebudayaan pop, busana, aksesoris hingga dandanan yang juga merupakan bagian dari kebudayaan pop yang menampilkan tampang, dandanan, dan gaya hidup masyarakat Barat.

Artikel-artikel yang disajikan dalam majalah Kosmopolitan ini juga sebagian besar merupakan artikel dari majalah aslinya yang berbahasa inggris. Secara konteks nilai dan kebudayaan di Indonesia, terkadang ada beberapa artikel yang tidak sesuai meskipun telah mengalami pelokalan dalam segi bahasa maupun konteksnya. Selain itu, sampul dan isi majalah Kosmopolitan menampilkan slogan fun fearless female. Kata-kata fun fearless female mengacu pada konsep wanita yang modern dalam arti wanita yang ingin maju, yang mendahulukan karier, yang ingin membahagiakan dirinya sendiri dengan mengejar karier, bukan wanita yang merasa harus segera berkeluarga pada usia yang sesuai dengan norma yang berlaku di masyarakatnya. Kosmopolitan seperti akan menciptakan wanita-wanita modern yang memiliki positive thinking, berani bertanggung jawab, berani 
menikmati hidup atau berani mencoba dengan slogan fun fearless female. Kosmpolitan Indonesia bahkan membuat acara annually untuk memilih fun fearless female of the year, sebagai salah satu bentuk bahwa majalah franchise ini sukses diterima oleh khalayak di Indonesia.

Di sinilah kemudian majalah hadir dan menampilkan realitas serta mempengaruhi kenyataan melalui sampul majalah. Kosmopolitan menghadirkan kenyataan wanita Barat sebagai wanita modern dengan kepribadian yang bahagia dengan diri dan kariernya, selalu berpikiran positif, dan percaya diri dengan penampilannya. Pada saat yang bersamaan, Kosmopolitan pun hendak menciptakan sosok wanita Indonesia menjadi wanita modern. Khalayak kemudian mengidentifikasi diri dengan makna yang ditimbulkan oleh citraan tersebut dan membuat representasi budaya tersebut berfungsi dalam hidup mereka sehari-hari, dengan menjadikannya sebagai gaya hidup. Kosmopolitan dan majalah-majalah sejenis sebenarnya merupakan mesin pengeruk uang yang berusaha mendominasi mode dan gaya hidup masyarakat, khususnya wanita perkotaan dengan menggunakan kecantikan dan keindahan tubuh selebriti sebagai komoditi yang menawan imajinasi khalayak karena keberadaan mereka disajikan secara amat menarik.

Majalah kemudian menjadi alternatif sarana untuk bersenang-senang (pleasure) dalam mengisi kekosongan waktu luang (leisure); majalah menjadi salah satu sarana pelarian diri bagi orang yang teralienasi. Ideologi yang dibawa media telah berhasil masuk ke dalam kehidupan sehari-hari seseorang, ketika seseorang memanfaatkan waktu luang dengan membaca majalah yang menyajikan nilai-nilai dan gaya hidup wanita perkotaan yang modern, tanpa orang tersebut menyadarinya karena menganggapnya sebagai sesuatu yang biasa. Radio Sindikasi MRA Media (Hard Rock FM dan Traxx FM) Salah satu bentuk ekspresi kebudayaan pop lainnya adalah musik atau lagu populer. Dalam hal ini, musik atau lagu populer yang sering diperdengarkan di radio-radio komersial merupakan tanda dalam kebudayaan pop. ${ }^{5}$

Format musik yang dipilih oleh radio Hard Rock FM (HRFM), yaitu pop cross-over; a mixture of hot adult contemporary, contemporary hits radio, modern rock and other kind of musics, yang berarti mencakup semua jenis lagu yang sedang populer atau menjadi hits yang sesuai dengan segmen pendengarnya, yaitu pendengar dengan SSE A-B yang berusia 20-30 tahun. HRFM tidak membatasi jenis musik yang diputar selama lagu tersebut populer dan sesuai dengan segmen pendengarnya. Sebagai lifestyle and

\footnotetext{
5 José Luiz Martinez, A Semiotic Theory of Music: According to A Peircean Rationale, http://www. pucsp.br/ cos-puc/rism/jlm6ICMS.htm
} 
entertainment station musik hanya sebagai companion, di mana fokus siaran(basic program)-nya lebih ditekankan kepada informasi lifestyle and entertainment. Sementara itu, format musik yang dipilih oleh Trax FM adalah Contemporary Hits Radio (CHR), di mana lagu-lagu yang diputar adalah yang disebut sebagai lagu-lagu Top-40.

Hal ini berarti lagu-lagu populer yang diputar di radio ini adalah lagulagu baru dengan komposisi $80 \%$ lagu baru dan sisanya lagu lama dalam satu jam siaran. Basic program Traxx FM adalah musik, dengan slogan: Music, all music, and nothing but music, yang diperkuat dengan sebutannya sebagai the grooviest music station. Berbeda dengan HRFM, Traxx berupaya menjangkau segmen pendengar yang berusia 15-25 tahun. Berdasarkan format musik yang dipilih, baik oleh HRFM maupun Traxx FM, maka lagu-lagu yang diputar, dapat dikategorikan ke dalam jenis lagu Rock and Roll, dan Jazz. Karakteristik lagu-lagu saat ini, semakin beraneka ragam dan selalu mengikuti selera pasar, serta penyanyinya yang senantiasa memperhatikan penampilannya dengan mengikuti atau bahkan menciptakan tren terbaru.

Lagu-lagu tersebut dengan mudah timbul tenggelam karena orang lekas puas, cepat bosan, dan jenuh terhadap sesuatu hal di balik terpaan kebudayaan pop. Lagu-lagu tersebut juga menjadi suatu komoditi yang mengikuti kriteria standardisasi produk, seperti halnya barang-barang komoditi massal lainnya. Standardisasi membuat lagu yang didengar di Indonesia sama dengan lagu yang didengar di Amerika. Dalam hal ini, HRFM dan Trax FM menjadi media yang menyebarkan komoditi massal tersebut kepada masyarakat Indonesia pada umumnya dan generasi muda kelas menengah perkotaan pada khususnya, yang sekaligus membentuk selera musik global generasi muda tersebut. MTV misalnya, dengan tagline it's all about music telah membuktikan bahwa musik dan semangat yang dipancarkannya mampu membentuk satu gaya hidup anak muda. MTV telah menjadi media hiburan dan informasi yang bersifat gaya hidup perkotaan modern yang mewakili jiwa anak muda melalui program musiknya.

Melalui media tersebut, HRFM dan Trax FM menjadikan musik sebagai saluran katarsis, eskapisme dan hedonisme yang mengalienasi generasi muda dari kejenuhan informasi tentang sosial politik. Sementara itu, dengan kekuasaan budaya yang dimilikinya, kaum muda memproduksi makna atas kehadiran musik tersebut. Mereka mengidentikkan diri dengan makna atau imaji yang ditimbulkan oleh musik tersebut dan mulai membangun cara hidup yang menurutnya menarik. Sebagai budaya pop, lagu-lagu yang diputar baik di HRFM maupun Trax FM, membuat semakin berkuasanya nilai-nilai hiburan dalam kehidupan generasi muda kelas menengah perkotaan. Melalui aliran-aliran musiknya yang beragam itu, musik memiliki konotasi sebagai 
musik komersial, mesin pengeruk uang, dan mendominasi mode. Musik dengan berbagai alirannya yang diproduksi dan dipasarkan secara komersial untuk memperoleh keuntungan kapital dari pasar sasarannya. Musik dibendakan dalam bentuk kaset rekaman, CD dan sekarang dalam bentuk RBT (Ring Back Tone), untuk kemudian dipasarkan dan diputar di stasiunstasiun radio di seluruh dunia. Musik telah menjadi sarana hiburan yang dikomoditaskan.

Musik lahir untuk memenuhi kebutuhan massa yang ingin menikmati hiburan. Ideologi pleisure dan leisure yang dibawa radio berhasil masuk ke dalam kehidupan sehari-hari seseorang dengan dimanfaatkannya waktu luang dengan mendengarkan musik atau bahkan menjadikan musik sebagai teman (companion) dalam beraktivitas. Kesadaran seseorang telah dikonstruksi untuk menjadikan musik sebagai bagian penting dari hidup. Sebagai komoditas musik diyakini bisa memberikan kehangatan dan makanan rohani bagi pendengarnya. Maka bukan hanya keuntungan kapital yang diperoleh tetapi juga selera, impian, dan imajinasi generasi muda dapat dengan mudah didikte, bahkan secara politik dapat diapatiskan dengan berhasil dikuasai dan dihegemoninya waktu luang mereka lewat ideologi yang dibawanya.

Jika dilihat dari perspektif Marxis, majalah dan musik sebagai alat ideologi negara yang terkait dengan seni dan budaya, merupakan suatu sarana hiburan yang menarik, apalagi dengan ditampilkan sosok selebriti sebagai pemikat, serta beragamnya aliran musik dan imaji yang ditimbulkan oleh penyanyinya. Sebagai alat ideologi, fungsi dari hiburan tersebut, dalam hal ini fungsi latennya, dapat dikatakan untuk mengalihkan perhatian orang dari situasi sosial mereka yang sesungguhnya, mengalihkan perhatian mereka dan menghilangkan kejenuhan akan berita-berita politik yang tidak menentu. Majalah dan musik adalah bisnis hiburan yang besar yang hadir untuk satu tujuan, mendapatkan uang dengan memanfaatkan mereka yang teralienasi. Di satu pihak, majalah dan musik menjadi komoditas, objek untuk dijual dan diperdagangkan. Di lain pihak, orang pun memanfaatkan objek-objek komoditas tersebut untuk melarikan diri dari keterasingan mereka. Majalah dan musik tidak lagi sekedar berfungsi sebagai hiburan, tetapi melalui ideologi pleasure and leisure-nya itu, keduanya menjadi barang komoditi yang berusaha mendominasi dan menguasai selera generasi muda lokal. 


\section{Dampak Globalisasi Media Terhadap Regulasi Di Indonesia}

Jika ditelaah lagi, secara umum dampak globalisasi media pada tata sosial masyarakat Indonesia, maka akan ditemukan dampak positif dan negatif. Dampak positif yang bersifat konstruktif, bahwa fenomena globalisasi media massa di Indonesia adalah perubahan sosial politik yang meliputi keterbukaan, penonjolan isu demokratisasi, hak dan asasi manusia, termasuk juga kebebasan pers. Sementara itu, dampak negatif dari globalisasi media dapat juga dilihat dari fenomena masyarakat yang semakin konsumeristis, apatis, individualistis dan sebagainya. Meningkatnya globalisasi dan komersialisasi dalam sistem media massa memang layak untuk diantisipasi dan diamati lebih lanjut.

Fenomena globalisasi media dirasakan semakin sejalan dengan komersialisasi dan kapitalisme yang akhirnya merujuk pada konsep neoliberal. Ini bukanlah sesuatu yang aneh, mengingat berkembang pesatnya perkembangan teknologi digital dan teknologi satelit yang membuat pasar global semakin efektif dan menguntungkan. Hal-hal ini sebenarnya disponsori oleh institusi kapitalisme dunia seperti IMF, World Trade Organisation(WTO) dan World Bank. Dalam perkembangannya, sistem media global juga terbukti dalam pemberitaannya juga memiliki kewajiban untuk mendukung misi dari WTO, IMF, NAFTA, GATT, yang tidak lain bertujuan untuk mewujudkan sistem ekonomi dunia yang bebas (neoliberal) yang jelas menguntungkan mereka (McChesney, 2000).

Persoalan yang menyangkut industri dan pasar media di Indonesia merupakan hubungan yang saling mengandaikan dengan tetap mengambil pola kapitalisme global sebagai sistem besar yang mengatur hubungan tersebut. Globalisasi media di Indonesia dalam sejarahnya yang panjang tetap tidak bisa dipisahkan dengan pola hubungan yang bersifat saling silang atau tarik ulur kepentingan antara pihak pelaku-pengelola media di mana di dalamnya ada aspek kebebasan berekspresi dan tanggung jawab sosial pada masyarakat; pihak pemodal yang di dalamnya aspek orientasi pada keuntungan dan pihak negara di mana di dalamnya ada kewajiban serta hak pengaturan, kontrol-pembinaan media massa yang berkembang di Indonesia. ${ }^{6}$

Terlepas dari hal-hal yang disebutkan diatas, agaknya terlihat bahwa media massa global sangat mewarnai perkembangan media di Indonesia Setidaknya bahwa media di Indonesia sedikit banyak berwarna seragam dengan pola globalisasi yang berkembang. Dapat dilihat bahwa pola hubungan politik

\footnotetext{
${ }^{6}$ Dedy. N Hidayat, Pers dalam Revolusi Mei: Runtuhnya Sebuah Hegemoni, (Jakarta: PT. Gramedia Pustaka Utama, 2000), hal. 34
} 
ekonomi global saling berjalan timbal balik dan saling tergantung sama lain, saling mentransformasikan nilai guna media di hadapan masyarakat (berbagai berita politik, ekonomi, gosip selebritis yang bisa diubah menjadi tontona dan komoditas ekonomi yang laris), konsentrasi media secara horizontal, vertikal dan perusahan multinasional, misalnya MRA Group yang kemudian meluaskan bidang usaha otomotif (Harley Davidson, Mobil mewah Masserati atau Ferrari) merupakan salah satu diversifikasi horizontal, vertikal dari kepemilikan media elektronik (beberapa radio sindikasi HardRock FM, Traxx, Cosmopolitan FM, dan I radio), serta banyak media cetak (Harpers Bazaar, Kosmopolitan dII), termasuk juga didalamnya beberapa hotel, cafe, TV berlangganan yang berada pada payung holding company yang sama.

Selain beberapa dampak negatif yang disebutkan, timbul beberapa masalah lain akibat globalisasi media, antara lain: pertama, gejala globalisasi media massa membuka kondisi dunia yang borderless world. Kondisi dunia tanpa batas ini mengakibatkan apa yang sering disebut dengan penyeragaman secara global dalam sistem, pola dan budaya komunikasi dunia dan Indonesia pada khususnya. Kedua, kebijakan media global, terdapat ada dua dimensi dalam kebijakan media global, yaitu kebijakan internal (editorial) yang bersifat horizontal dan kebijakan politik-ideologi pelaku media yang bersifat vertikal. Dalam perkembangan kapitalisme global tidak jarang kedua dimensi tersebut saling bertabrakan kepentingan.

Tarik ulur kebijakan politik-ideologi yang dipunyai oleh pelaku media terkait dengan kebijakan-kebijakan publik yang dikeluarkan oleh pemerintah yang bersangkutan. Pada saatnya, kebijakan-kebijakan publik tersebut saling silang dengan kepentingan dan kebijakan pelaku media dalam konteks industri media yang mereka buat. Ketiga, globalisasi media massa semakin memperlebar jurang perbedaan arus informasi yang terjadi antara negara-negara maju dengan negara-negara berkembang, Indonesia contohnya. Seperti pada karakter pembentukan media massa di negara berkembang pada umumnya, secara luas dapat kita lihat dari sistem kepemilikan, pola produksi dan kebijakan internal yang tidak bisa dipisahkan dengan sistem kepemilikan, pola produksi dan industri media di negara-negara maju.

Inilah yang pada akhirnya akan membuat kepincangan arus informasi yang didominasi oleh media global. Kita dapat melihat bagaimana TV One Merujuk VOA TV sebagai salah satu sumber beritanya. Tahapan konsentrasi sistem kepemilikan, pola produksi dan distribusi, kebijakan internal media global (yang sering diwakili oleh media negara maju) akan menimbulkan tekanan yang berupa potensi teknologi baru dan konsentrasi ekonomi yang semakin memusat pada pelaku media besar. ${ }^{7}$

${ }^{7}$ Graham-Golding, dalam Curran-Gurevitch "Mass Media and Society, 1991 
Keempat, timbulnya masalah bagaimana sistem sosial dan regulasi sebuah negara dapat mewadahi berbagai ragam kepentingan yang masuk dan ditawarkan oleh media global. Artinya bahwa informasi pasar global yang diwujudkan dalam ide-ide komunikasi sosial masuk ke negara-negara berkembang tanpa melalui sensor yang diperlukan. Konsekuensi logis globalisasi yang bersifat borderless society mengakibatkan penetrasi tanpa batas tanpa perlu mengindahkan kedaulatan negara, masyarakat, dan individu. Kelima, adalah masalah yang timbul akibat poin keempat, yaitu munculnya berbagai masalah terutama pada masalah etis produksi, distribusi dan konsumsi isi media yang berisi tentang bagaimana hak privasi dapat dilindungi ketika hak tersebut berbenturan dengan hak publik untuk mengetahui dan mendapatkan keberagaman informasi.

Ini berarti bahwa dampak negatif dari globalisasi media tidak hanya berhenti pada tataran sosial-kolektif tapi juga pada tataran individual. Yang harus dipahami lebih mendalam adalah bahwa globalisasi media tidak bisa dikatakan bebas nilai dan bebas kepentingan, entah itu kepentingan ekonomi atau kepentingan politik. Masalah hukum atau penataan aturan main dalam media selalu mempunyai hubungan yang erat dengan masalah budaya politik (berkaitan dengan demikian pada masalah kekuasaan dan kontrol), soal budaya (berkaitan dengan demikian pada masalah simbolisasi-komodifikasispasialisasi-strukturisasi) serta masalah perekonomian nasional. ${ }^{8}$

Selama ini di Indonesia menyatakan bahwa hukum selalu berada di bawah kekuasaan politik. Hal ini mengakibatkan bahwa sering kali hukum Indonesia belum mampu menjadi alat yang adil bagi masalah-masalah politik, ekonomi dan sosial-budaya. Fakta ini menunjukkan betapa ketika kita mempunyai sistem hukum yang positif tapi tetap saja ketika sistem hukum tersebut berhadapan dengan masalah-masalah baru terutama dalam bidang komunikasi, tiba-tiba sistem hukum Indonesia menjadi gagap (lihat saja pelanggaran dengan menggunakan internet atau media massa nir-kabel yang belum ditampung secara positif dalam hukum Indonesia, atau pelanggaran privasi individu sehingga gambar tubuh atau kepalanya bisa dimanipulasi sehingga menjadi gambar yang tidak senonoh, atau beberapa televisi yang menayangkan film-film dewasa pada waktu jam anak-anak masih bangun, atau konsep tabloid cetak porno yang secara sewenang-wenang bisa memberikan gambar semi-vulgar pada siapa saja yang melihat, termasuk pada anak-anak di bawah usia).

\footnotetext{
${ }^{8}$ A. Muis, Indonesia di Era Dunia Maya: Teknologi Informasi dalam Dunia Tanpa Batas. (Bandung: PT. Remaja Rosdakarya, 2001), hal. 65
} 
Hal ini menunjukkan bahwa regulasi media di Indonesia belum mampu mengatur tayangan, liputan atau berita yang menstimulasi individualisme, sarkasme, atau hedonisme berlebihan. Ini berarti memang hukum nasional di satu sisi kuat ketika dia bisa dipergunakan untuk kepentingan politik praktis. Tapi di sisi lain, terlihat hukum Indonesia masih lemah menanggapi fenomena globalisasi media. Masalahnya adalah bagaimana kita bisa membangun regulasi yang bisa mengantisipasi dan mengontrol dampak negatif yang dihasilkan oleh globalisasi media. Setidaknya ada tiga pihak yang berkepentingan dalam regulasi dan globalisasi media di Indonesia. Pertama adalah masyarakat komunitas (society-publik).

Pertanyaan kritis untuk memahami peran dan fungsi regulasi media, terutama dalam era globalisasi media, adalah sejauh mana regulasi media mampu melindungi, memberdayakan, memampukan masyarakat menjadi pihak yang mandiri dalam terpaan informasi media baik lokal, nasional maupun global. Artinya apakah regulasi media di Indonesia mampu menciptakan dan membentuk ranah publik, komunitas atau media yang akomodatif sehingga publik dapat menyuarakan aspirasi secara efektif dan bebas. Kedua adalah pasar bisnis-industri media di Indonesia. Salah satu ciri globalisasi adalah desakan kuat atas bisnis internasional yang lintas batas teritorial negara, termasuk di dalamnya bisnis dan industri media. Terpaan sistem kapitalisme media global sangat dimungkinkan masuk dan media Indonesia masuk sistem besar kapitalisme media dunia. Kepentingan kapitalisme global adalah memperluas pasar media di seluruh dunia, termasuk ke Indonesia. Apalagi Indonesia mempunyai potensi pasar yang luar biasa. Faktor pasar ekonomi global dalam ekonomi Indonesia berkepentingan untuk menjadi tempat "aman" para awak dan pelaku industri media di Indonesia.

Bentuk kapitalisme media telah dilakukan oleh pebisnis Indonesia, tapi masih terbatas pada pelaku atau pemain media besar, seperti kelompok Kompas-Gramedia (menguasai bisnis media secara vertikal maupun horizontal), kelompok Media Indonesia, MRA Media Group, Jawa Pos Grup, dan MNC. Pihak ketiga dalam bahasan regulasi media adalah pemerintah. Artinya pemerintah Indonesia diharapkan menjadi "wasit" sekaligus "fasilitator" yang baik bagi iklim perkembangan sosial-politik dan ekonomi media yang hidup di Indonesia. Sejarah media Indonesia menyatakan bahwa sering terjadi dominasi yang dilakukan oleh pemerintah dalam pembicaraan media di Indonesia. ${ }^{9}$ Tapi dalam era reformasi, pemerintah justru lemah pada saat berhadapan "kebebasan pers/media". Posisi berubah-ubah yang dimiliki

\footnotetext{
${ }^{9}$ Dedy. N Hidayat, Pers dalam Revolusi Mei: Runtuhnya Sebuah Hegemoni, (Jakarta: PT. Gramedia Pustaka Utama, 2000), hal. 250-259
} 
pemerintah cukup menyulitkan pihak-pihak yang concern terhadap kedewasaan media di Indonesia untuk bersikap secara benar dan proporsional.

Pertanyaan penting mengenai regulasi media di Indonesia yang berkaitan dengan pihak-pihak yang berkepentingan di atas adalah sejauh mana regulasi media memberikan jaminan dan penciptakan mekanisme pasar media yang sehat, kompetitif, sehat dan adil. Pola globalisasi media mengekor dan berpenetrasi ke dalam sistem sosial negara tertentu dengan membawa fungsi ekonomi dan politik (Feintuck, Mike, 1998). Jelas kedudukan hukum yang sampai sekarang masih lemah, membuat macetnya penerapan dan antisipasi bagi perkembangan media global di Indonesia. Ketika ada persoalan kepemilikan silang yang dilakukan oleh beberapa elite sosial atau pemain besar dari kelompok media yang mapan dan didukung dengan kekuatan dana - backing politik yang cukup representatif maka bisa saja regulasi media yang disepakati menjadi buyar, dilanggar/diabaikan begitu saja. Contoh kasus Ted Turner pada "TIME" yang juga menguasai bisnis TV, information technology dengan mengakuisisi AOL - American On-Line). Contoh lainnya adalah reaksi nyata dari Surya Paloh ketika RUU penyiaran mengatur kepemilikan silang media. Bagi Surya Paloh, regulasi tersebut justru dilihat sebagai penghambat demokrasi, padahal pada negara-negara paling liberal (negara bagian Amerika) pun sistem kepemilikan silang itu sangat dibatasi dan menjadi konsensus publik.

Regulasi globalisasi media seharusnya mampu menemukan ruang publik yang lebih luas dan bertambah luas. Artinya regulasi media juga menciptakan ruang demokrasi dengan mendorong dan menstimulasi media komunitas (community media) yang membawa aspirasi original masyarakat komunitas tersebut. Dalam RUU penyiaran, hal itu memang diatur tapi masalahnya lembaga penyiaran komunitas yang diatur dalam RUU tersebut tidak secara eksplisit mampu dengan mandiri, swasembada, self-regulatory menjadi alat penguatan masyarakat (lihat RUU penyiaran ps 18). Kemampuan masyarakat untuk menyediakan informasi alternatif di samping terpaan arus informasi yang begitu dahsyat membawa dampak penting bagi pendidikan dan pemberdayaan masyarakat sebagai civil society. 


\section{Daftar Pustaka}

Aronowitz, Stanley 2009, Journal: Situations, vol. 2. The Ignored Philosophers and Social Theorist: The Work of Henri Lefebvre.

Currant, James and Michael Gurevitch 1991, Mass Media and Society, Edward Arnold, London.

Feintuck, Mike 1998, Media Regulation, Public Interest, and The Law. Edinburg University Press. London.

Hidayat, Dedy. N. 2000, Pers dalam Revolusi Mei: Runtuhnya Sebuah Hegemoni, PT. Gramedia Pustaka Utama, Jakarta.

Ibrahim, Idi Subandy 2000, Jurnal Ikatan Sarjana Komunikasi Indonesia, Industri Pers dan Prospek Kebebasannya, Vol. V/Oktober, hal.163 Kebangkitan "Generasi Ne(X)t" dalam Rimba Budaya Pop: Parodi di Balik Budaya Musik Kawula, Penerbit PT Remaja Rosdakarya, Bandung.

McChesney, Robert. W 2000, Rich Media Poor Democracy, Communication in Dubious Times, The New Press, New York.

McQuails, Denis. 2000, Mass Communication Theories, Fourth Editions. Sage Publication, London.

Mosco, Vincent. 1996, The Political Economy of Communication: Rethinking and Renewal, Sage Publication. London.

Muis, A. 2001, Indonesia di Era Dunia Maya: Teknologi Informasi dalam Dunia Tanpa Batas, PT. Remaja Rosdakarya, Bandung.

Undang-Undang Republik Indonesia Nomor 32 Tentang PENYIARAN tahun 2002

www.mra.co.id 